\title{
AN ASSESSMENT OF THE RELATIONSHIP AMONG CARGO-THROUGHPUT, VESSEL TURNAROUND TIME AND PORT-REVENUE IN NIGERIA. (A STUDY OF LAGOSPORT COMPLEX)
}

\author{
Sodiq Olusegun Buhari ${ }^{1 *}$, Dr Obed Ndikom ${ }^{2}$, Nwokedi Theophilus. ${ }^{3}$ \\ *1,2,3 Department of maritime management technology, federal university of technology, owerri.
}

*Corresponding Author: -

\begin{abstract}
: -
A knowledge-based economy remains the propeller for development in most developing nations. Adequate knowledge of the quantitative relationship among vessel turnaround-time, Cargo-throughput and revenue generated by a seaport constitutes a determinant factor in forecasting the long-run financial performance of terminal operators and ports authorities. The study investigated the quantitative relationship among vessel turnaround-time, cargo- throughput and port-revenue and the effect of such relationship on port performance in Nigeria. Since port performance, measureable by the level of revenue generated over time is dependent on cargo-throughput and ship turnaround-time, multiple regression method was used in analyzing the time series data of 15 years. The result of the analysis reveals a significant impact of ship turnaround-time and cargo-throughput on port-revenue. The relationship between port-revenue and each of cargo-throughput and ship turnaround-time is: $Y=106.22 X_{1}+55.064 X 2-10753.216+e$. The study recommended improved investment in port infrastructure to improve ship turnaround-time and cargo-throughput, and maximize port-revenue.
\end{abstract}

Keywords: Port-Revenue, Vessel-Turnaround-time, Cargo-Throughput 


\section{INTRODUCTION}

Seaports and terminals are transport hubs for vessel husbandry, cargo operations and other forms of shore based operations aimed at harnessing the ship, cargo and crew for offshore operations and voyage. Ports and port authorities represent strategic gateways into the economies of nations just as the entire global maritime industry situates at a very focal point in global economics of national and international development [1]. Without it, it becomes difficult to transfer import and export, through the supply chain, the manufactured goods and equipments of the developed western world to the consumer markets of developing nations as well as raw materials from the untapped resources of the developing nations of Africa, to the developed western world, since other modes can only carry a minor percentage of the capacity of the maritime transport system. This very inevitable role of maritime transport vests on the seaports and terminals a very important economic power to influence the trend and nature of global trade flow, as well as impact on global trade practice by way of cost, time of doing business, loss control and safety of investment, security, etc. Chrzanowski [1] notes that a multiply of maritime industry business activities and operations depends on the seaports to be concluded and are impacted on by the activities and service characteristics of the ports. Thus, increase in port service time, cargo dwell time, port service cost, total cost of port usage may impact positively or negatively on port performance [2]. It is believed that port performance is a multiple variable factor by which the productiveness or otherwise of a port may be assessed [3]. One such variable is the cargo throughput of the port which represents the total tonnage of cargo that a port is able to handle over a period of one year. Since a major component of the ports business operations is cargo handling operations, it has been professionally acknowledged that decline in cargo throughput volume is a sure indication of poor port performance[3][4]. Adebayo [4] views that ship traffic size of a port will sure impact on cargo throughput volume, while port policy, service cost and time, safety and security of ship while in port, are variable that will affect the ship traffic size of a port. Ship/vessel time represent the total time it takes from when a ship arrived a port to the time it left the port after having been worked ( concluded loading or discharging operations). This factor of ship turnaround time indicates the efficiency rate of the port authorities in time usage [5]. Higher ship turnaround time is an indication that vessels spend longer than necessary in such port, and since time is an important component of cost determination in transport, higher ship turnaround time imposes higher cost of port usage which from the customers perspective is a sure sign of poor port performance [5][6]. Since ports in modern times aim to earn revenue and make profit, a most appropriate factor to assess the performance and productivity of the port, from operators' perspective is port revenue. The port revenue in this case is the total income earned by the ports from all its operations and services over time. Kendall [7] believes that to optimize the impact on the ports on the global maritime industry national economies, the productivity of the port in terms of revenues performance is an important variable that must be analysed.

Fagerlo [8] opines that implementation optimal policies in maritime administration in the global maritime industry is all that is needed to raise impact of ports and fleet schedules on global export and import trade. In Nigeria, such optimal revenue policies in the administration of the port may only be possible when the relationships existing among port revenue and other variables that affect it are quantitatively determined and modeled. The model of relationship between port revenue and the correlated may then serve as basis for planning future revenue generation of the ports, without violating policy requirements for costing of port services with a view to achieving optimal port service cost [9]. Maduka[10] observes that the present maritime industry of Nigerian has lacked the this very approach of determining optimal port service costs by modeling revenue factors of the Nigerian ports, so that future revenue targets can be extrapolated and strategically collected to optimize the economy of Nigerian Ports Authority (NPA). This in line with the opinion of Mouroa[11] that ships compete for use of hub ports which offer optimal impact on cost and time. The implication is that the failure of any port to transform to a hub port by optimizing the benefits of port usage to ships while also optimizing her revenue base may lead to be relegated to a scope port, only to be used to service more competitive ports. Olson [12] analysis on the concept of fleet scheduling and routing in the transport industry also stressed the importance of optimizing costs and performance parameters. For Nigerian ports to achieve a hub status in the west and central African sub-regions, cost and time parameters of services consumption must be optimized. Then for the port to make serious economic impact and progress in Nigeria, port revenue must equally be optimized and this can only be done when a quantitative model of the effect of the relationship among port revenue, ship turnaround time, cargo throughput, etc have been determined as basis for planning[13].

The relationship among cargo throughput, ship turnaround time and port revenue and the effect in determination of equilibrium levels in port service cost, efficiency and port service time utilization and port productivity in Nigeria over the years have been neglected. Ndikom[13] analyzed the existing relationship between port productivity ship traffic volume but could not extend it to measure the impacts ship turnaround time and cargo throughput on port performance. The later variables however prove to constitute very strong factors in explaining the trend of performance of Nigerian ports from the revenue perspective. The fact is that while turnaround time is an important factor of consideration by vessel operators in the decision to make port choice, cargo throughput directly affects revenue performance and productivity of the ports. Nigerian ports have continued to lose ship traffic to neighboring west African ports due to higher ship turnaround time and other negative indices, the ports have thus lost revenue over the years and as such have recorded minimal performance than her potentials [13][4]. From the foregoing, it is important that a critical assessment of the challenges facing cargo throughput, vessel turnaround time and port revenue in Nigeria be carried out.

Ship operators have on several occasions faulted some operational and managerial policies with regards to vessel and cargo operation within the ports system very confusing, leading to operational delays and high ship turnaround time. This is because the high demand experienced in port service consumption is equally characterized by administrative and infrastructural capacity unavailability and inefficiency [3, 4]. Yet, Nigerian port operators in today's knowledge 
economy may not have understood the basic relationship among port revenue, cargo throughput and ship turnaround time [13]. Knowledge of such a relationship will aid in fashioning out strategic port infrastructural investment policies that will cause decline in ship turnaround time while at the same time improving cargo throughput and revenue of the ports. The present research seeks to establish a relationship among port revenue as a productivity variable and ship turnaround time and cargo throughput as service variables to enable equilibrium be established among them, so that port performance parameters may be optimized.

Statistical reports from the Nigerian Ports Authority [14] indicates consistent increments in ports revenue generation, cargo throughput for both export and import cargo, as well as ship traffic statistics of the ports within the period of the review. See figures 1 and 2 below:

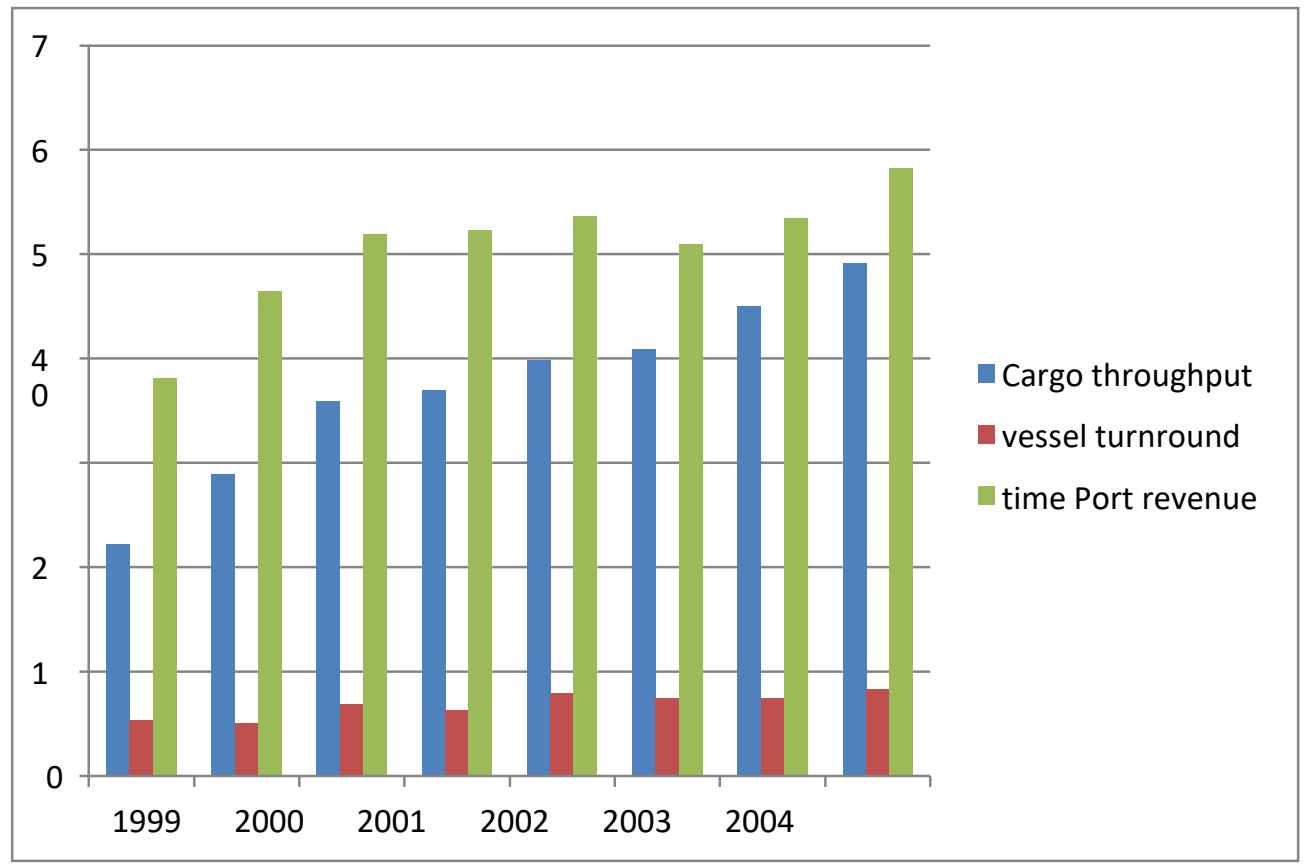

Figure 1a. multiple bar chart representation of annual port revenue, cargo throughput and vessel turnaround time from 1999 to 2006. Source: NPA report 2014.

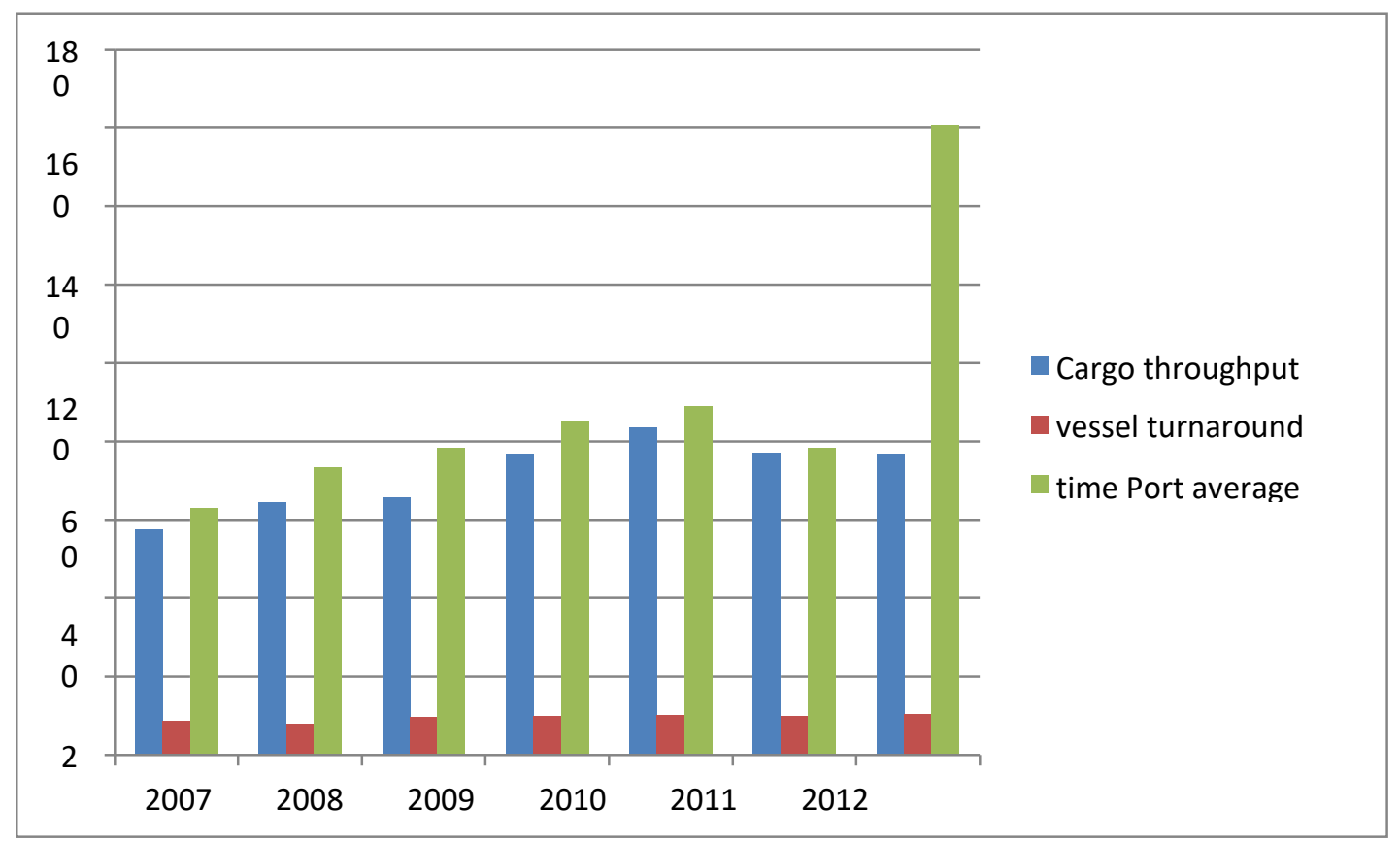

Figure 1b: multiple bar chart representation of annual port revenue, cargo throughput and vessel turnaround time from 2007 to 2013. Source: NPA report 2014

However, it is not easy to clearly understand the model and nature of relationship among the three and how to further determine if such a relationship yields optimal beneficial result. This necessitates the modeling of the relationship among the three variables in this work to understand how both cargo throughput and vessel turnaround time effect port revenue. Such model will provide the needed knowledge of economic relationship to drive the revenue generation capacity of the ports to optimal level by informed strategic manipulation of cargo throughput volume and vessel 
turnaround time using policy instruments and informed investment in port infrastructure.

\section{Objectives}

The main aim of the study is to determine the impact of cargo-throughput and ship turnaround-time on port revenue in Nigeria from 1999 to 2013. Since the revenue generated by port authorities and terminal operators serves as proxy in measuring the level of port performance, and since port performance in terms of revenue generated by ports is dependent on vessel traffic statistics and cargo-throughput of the ports while vessel traffic statistic is affected by ship turnaround-time. The study therefore aims basically to find the effect of cargo-throughput and ship turnaround-around time on port revenue.

The specific objectives include:

- To assess the impact of cargo throughput on port revenue from 1999 to 2013.

- To evaluate the effect of ship turnaround time on port revenue within the period covered in the study.

- To ascertain the trend of port revenue, cargo throughput and ship turnaround time of Nigerian ports within the period covered in the study.

\subsection{Research questions}

1. What is the quantitative relationship expresses the impact of cargo throughput of the Nigerian ports on port revenue?

2. Does ship turnaround time significantly affect port revenue?

3. Does the present trend suggest significant increases in trend of port revenue, cargo throughput and ship turnaround?

\subsection{Hypothesis}

H01: There no significant impact of Cargo throughput volume on port revenue in Nigeria within the period covered in the study.

H02: Ship turnaround time does not significantly affect port revenue.

H03: Port revenue, cargo throughput, and ship turnaround time of the Nigerian ports does not show significant increase in trend within the period covered in the study.

\section{Methodology}

This research employs a case study approach in which the Lagos port complex, Apapa, Nigeria was used as case study. The time series data covering a period of 15 years, from 1999 to 2013 was gathered from various editions of the Nigerian ports authority (NPA) annual statistical report. The data gathered include data on each of the variables namely: port- revenue, cargo-throughput and ship turnaround-time of the Apapa ports, Nigerian, each year from 1999 to 2013. The study used the symbols $Y, x_{1}$, and $x 2 \ldots x n$ (where $\left.n=15\right)$ to denote port revenue, cargo throughput turnaround of the ports in each covered by the study. Since port performance measured by port revenue as a productivity indicator is dependent port cargo throughput and ship turnaround time, $\mathrm{X}_{1}$ and $\mathrm{X}_{2}$ where used as the independent variables. The multiple regression method of statistical analysis was then used to analyze the data to assess the nature of the relationship and impact of of the independent variables ( $\mathrm{X}_{1}$ and $\left.\mathrm{X}_{2}\right)$ on the dependent variable (Y). Multiple regression analysis is an econometric tool that models the natures of relationship and impact of multiple independent variables, as in this case on a single dependent variable.

Since the aim of the study is to assess the relationship and effect of cargo-throughput and ship turnaround-time on port revenue, the multiple regression method gives the most appropriate method for this nature of impact assessment. This is because regression is a key statistical tool for impact modeling. The model specification is as shown: $\mathrm{Y}=\mathrm{a} 1+\mathrm{b} 1 \mathrm{X} 1+$ $\mathrm{b}_{2} \mathrm{X}_{2}+\mathrm{e}$, where $\mathrm{a} 1$, and $\mathrm{e}$ are the constant term and the error term respectively, b1, b2 are coefficients. The $\mathrm{t}$ distribution or t-statistics results corresponding to the decisions variables were used to test the proposed null hypotheses $\mathrm{H} 01$ and H02. However, in using the multiple regression analyses statistical tool, the researcher assumed that there exist a linearity of relationship between the dependent variable and the independent variables.

In order to achieve the third objective of the research, trend analysis was also carried out using the ordinary least square (OLS) method of regression to ascertain if each of the variables port revenue (Ytr), cargo throughput (X1tr) and vessel turnaround time $\left(\mathrm{X}_{2} \mathrm{tr}\right)$ all show significant increases in trend over the period. $\mathrm{Y} t \mathrm{tr}, \mathrm{X}_{1} \mathrm{tr}, \mathrm{X}_{1} \mathrm{tr}$, represents the trend of port revenue, cargo throughput and vessel turnaround time within the period of the study. This is because in line with the third objective of the study, only a trend analysis can determining if there exists the trend of each variable over the period of time. To carry out the trend analysis, time was employed as the independent variable $t($ where $t=t 1-t n, n=$ 15 ), while the decision variable of port revenue, cargo throughput and ship turnaround time were employed individually as the dependent variables. While the $\mathrm{t}$ - statistics indicate the significance level of the trend model, the positivity and/or negativity nature of the coefficient terms, indicates if the trend is increasing or decreasing over the period.

Employing the methods discussed above, the study achieved the objectives set out in the previous chapters.

\subsection{Limitations of the study}

The data used for the research was sourced from Nigerian Ports Authority (NPA) annual statistical report for various editions. As a result, the accuracy of the result and findings is dependent on the accuracy of the data used. 


\section{Data presentation}

Table 1: Values of Port revenue, cargo throughput and vessel turnaround time in Nigeria ports from 1999 to 2013

\begin{tabular}{|c|c|c|c|c|}
\hline $\begin{array}{c}\text { Time } \\
=\mathbf{t n}\end{array}$ & YEAR & $\begin{array}{c}\text { Annual Average } \\
\text { revenue(Million }\end{array}$ & $\begin{array}{c}\text { Cargo throughput } \\
\text { (Million Tonnes) X1 }\end{array}$ & $\begin{array}{c}\text { Vessel turnaround } \\
\text { time (Hours) X2 }\end{array}$ \\
\hline & & Naira) Y & & 5.31 \\
\hline 1 & 1999 & 38.1 & 22.23 & 5.01 \\
\hline 2 & 2000 & 44.4 & 28.93 & 6.91 \\
\hline 3 & 2001 & 51.9 & 35.94 & 6.30 \\
\hline 4 & 2002 & 52.3 & 36.99 & 7.89 \\
\hline 5 & 2003 & 53.6 & 39.77 & 7.44 \\
\hline 6 & 2004 & 50.9 & 40.82 & 7.4 \\
\hline 7 & 2005 & 53.4 & 44.95 & 8.31 \\
\hline 8 & 2006 & 58.2 & 49.17 & 8.6 \\
\hline 9 & 2007 & 62.9 & 57.47 & 8.7 \\
\hline 10 & 2008 & 73.3 & 64.37 & 9.9 \\
\hline 11 & 2009 & 78.3 & 65.78 & 10.2 \\
\hline 12 & 2010 & 85.1 & 76.74 & 10 \\
\hline 13 & 2011 & 89.1 & 83.46 & 10.50 \\
\hline 14 & 2012 & 78.3 & 77.09 & \\
\hline 15 & 2013 & 160.5 & 76.89 & \\
\hline
\end{tabular}

Source: NPA annual statistical report, various editions.

Table 1 above is the statistical data on the decision variables sourced from NPA annual statistical report showing the annual values of port-revenue ' $Y$ ', cargo-throughput ' $X$ '1 and ship turnaround-time ' $X$ '2 for a 15 years period from 1999 to 2013. trend in port revenue, cargo throughput and vessel traffic statistics of the ports from 1999 to 2013 . The figures represent the input data used for the statistical analysis.

\section{5 . Data analysis and results.}

Table 2: ouput result of multiple regression analysis using $Y$ as dependent variable.

\begin{tabular}{|c|c|c|c|}
\hline Mode 1 & Variables Entered & Variables Removed & Method \\
\hline 1 & $\mathrm{X} 1, \mathrm{X} 2, \mathrm{Y}$ &. & Enter \\
\hline
\end{tabular}

a. Dependent Variable: Y

b. All requested variables entered.

\section{Model Summary}

\begin{tabular}{|c|c|c|c|c|}
\hline Model & $\mathrm{R}$ & $\mathrm{R}$ Square & Adjusted R Square & Std. Error of the Estimate \\
\hline 1 & $.998^{\mathrm{a}}$ & .999 & .718 & 5511.518098 \\
\hline
\end{tabular}

a. Predictors: (Constant), X1, X2

ANOVA $^{\mathbf{a}}$

\begin{tabular}{|c|c|c|c|c|c|c|}
\hline \multicolumn{1}{|c|}{ Model } & Sum of Squares & df & Mean Square & F & Sig. \\
\hline \multirow{2}{*}{1} & Regression & 68536400.493 & 2 & 34268200.247 & 1.128 & $.006^{\mathrm{b}}$ \\
& Residual & 364521980.944 & 12 & 30376831.745 & & \\
& Total & 433058381.437 & 14 & & & \\
\hline
\end{tabular}

a. Dependent Variable: Y

b. Predictors: (Constant), $\mathrm{X}_{1}, \mathrm{X}_{2}$

Coefficients ${ }^{\text {a }}$

\begin{tabular}{|c|c|c|c|c|c|c|}
\hline & \multirow[t]{2}{*}{ Model } & \multicolumn{2}{|c|}{ Unstandardized Coefficients } & \multirow{2}{*}{$\begin{array}{l}\text { Standardized Coefficients } \\
\text { Beta }\end{array}$} & \multirow[t]{2}{*}{$\mathrm{T}$} & \multirow[t]{2}{*}{ Sig. } \\
\hline & & B & Std. Error & & & \\
\hline \multirow{3}{*}{1} & (Constant) & -10753.216 & 9764.179 & & -1.101 & .292 \\
\hline & $\mathrm{X} 1$ & 106.220 & 76.256 & .376 & 2.393 & .089 \\
\hline & $\mathrm{X}_{2}$ & 55.064 & 66.965 & .222 & .822 & .427 \\
\hline
\end{tabular}


Table3: summary of output by trend analysis.

\begin{tabular}{|c|c|c|c|}
\hline parameter & $\begin{array}{c}\text { Ytr }=\text { port revnue } \\
\text { trend }\end{array}$ & $\begin{array}{l}\text { X1tr }=\text { throughput } \\
\text { trend }\end{array}$ & $\mathrm{X} 2 \mathrm{tr}=$ turnaround time \\
\hline Intercept $=\mathrm{a}$ & 128.4 & 80.37 & 10.54 \\
\hline Coefficient $=$ b1 .... b3 & 1.82 & .631 & .574 \\
\hline $\mathrm{R}^{2} \begin{array}{c}\text { coefficient of } \\
\text { determination }\end{array}$ & 0.1383 & 0.1715 & .0 .7034 \\
\hline
\end{tabular}

Sources: software output.

\section{Discussion of results and findings}

The result of table2 shows that strong positive correlation exists among port revenue, cargo throughput and vessel turnaround time. The multiple $\mathrm{R}$ is 0.998 which indicates a very high degree of positive relationship/ correlation among the three variables. This implies that the levels of cargo-throughput and ship turnaround-time affects to a great extend the revenue performance of the ports since about $99 \%$ of correlation exist among the and since port revenue is dependent on cargo-throughput and ship turnaround-time values. Policy legislations and port service strategies that improves the values of the two explanatory variables will thus improve port revenue performance. The quantitative equation which models the relationship and impact of cargo throughput and ship turnaround time on port revenue is: $\mathrm{Y}$ $=106.22 \mathrm{X} 1+55.064 \mathrm{X} 2-10753.216+\mathrm{e}$. The coefficient of determination $\mathrm{R}^{2}$ which measures the explanatory power of the model is about 0.99 , indicating that about $99 \%$ variations in port revenue is explained by port cargo throughput and ship turnaround time. This is in line with the findings of Ndikom [12] that cargo throughput volume is a major determinant of level of port revenue. Ndikom[12] further notes that ship turnaround time exerts a strong influence on cargo throughput level of a port, while turnaround time record of a port itself influences port choice by ship operators. The strong correlation among the three variables as deduced from the result output supports the earlier observations of Ndikom [12].

The policy implication is that port management policies should be tailored to attract and/or generate higher volume of cargo throughput in order to increase revenue earnings and sustain port operations. Policies should aim to increase vessel traffic and cargo throughput and decreasing ship turnaround time. This is because any port policy that increases ship turnaround time will certainly decrease vessel traffic and cargo throughput volume, and this is not good for port revenue. A geometric plot of the port revenue level against cargo throughput volume in figure 3 below gives a clearer representation of the relationship.

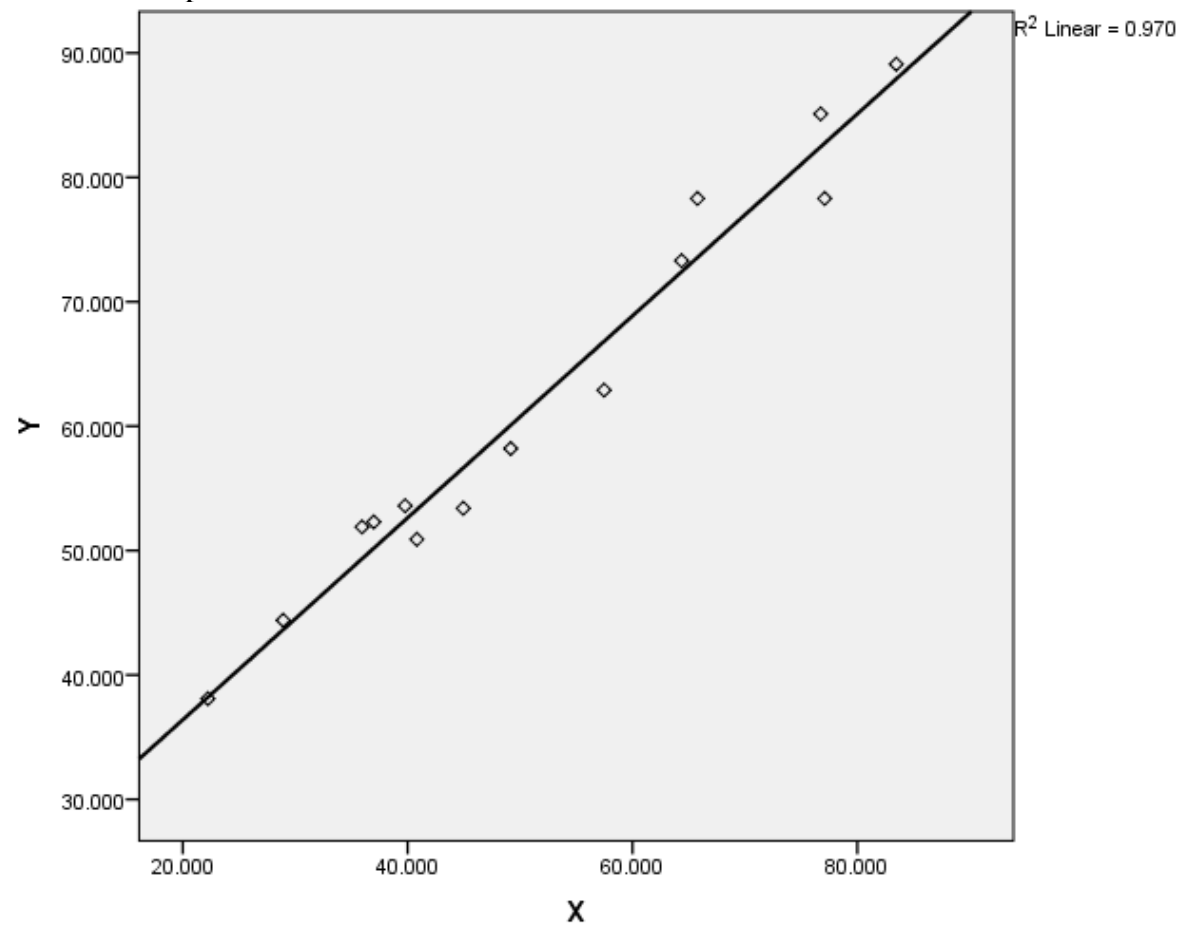

Figure3: Geometric plotting of port revenue against cargo throughput. Source: authors' calculation.

The geometric plot equally shows that port revenue was directly proportional to cargo throughput from 1999 to 2013 . That is, as cargo throughput in the Port increases, the port annual revenue increases. The degree of correlation between cargo throughput and port revenue is 0.97 . This is in line with the earlier results obtained by the use of multiple regression method as shown in table2. This shows about $97 \%$ correlation, inferring that a strong positive relationship exist between the duo. The gradient of the plot is 0.91 naira per ton, implying that a unit increase in tonnage of cargo handled increases port revenue by approximately 1 naira. 
The policy implication as earlier stated is that port management policies should be tailored to attract and/or generate higher volume of cargo throughput in order to increase revenue earnings and sustain port operations.

A geometric plot of the relationship between port revenue and vessel turnaround time equally shows similar result. See figure 4 below.

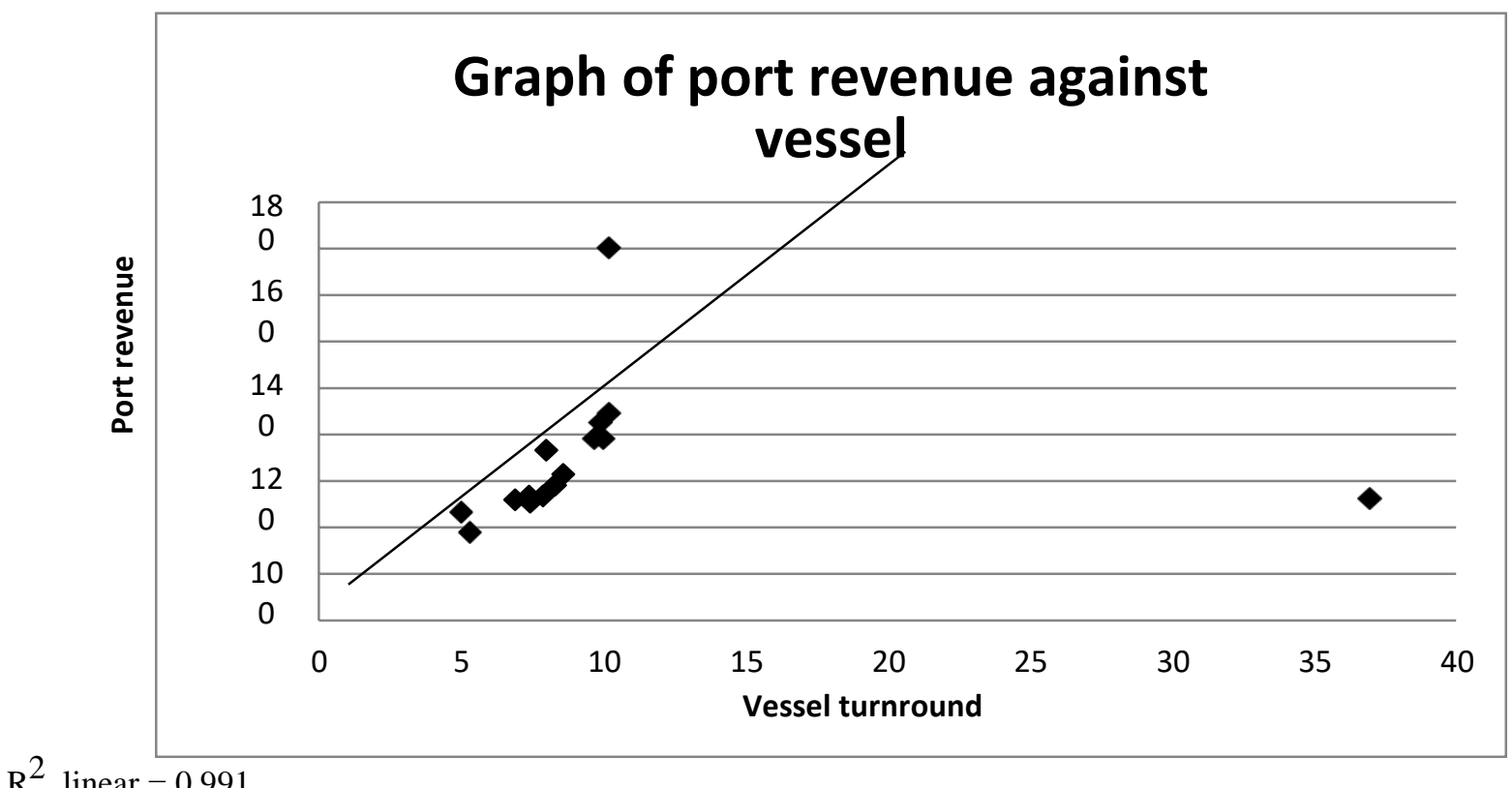

Figure4: Geometric plotting against vessel turnaround time. Source: Authors Calculation

The graph similarly indicates that annual port revenue is directly proportional to vessel turnaround time from 1999 to 2013. That is, as vessel turnaround time in the Port increases, the port annual revenue in the Port increases. The correlation coefficient of 0.991 indicates a $99.1 \%$ correlation between port revenue and ship turnaround time. This means that a strong positive relationship exist between the duo. The gradient of the plot is 1.33, indicating that on the average; 1.3 million naira was generated as port revenue per ship hour (per ship turnaround time).

The policy implication is that Nigeria port's charging system is such that ship operators pay more as they spend longer time in port and pay less when time spent in port/berth decreases. This in line with the global trend as observed by [9] . However, the increasing trend in vessel turnaround time in the Nigerian ports is evidence that investment in necessary port infrastructure that quickens vessel handling and reduces time stay at berth is still inadequate. Robust port investment policy is needed to push the consciousness of the port authority to the need for routine investment in port infrastructures and drive them to make such investments, so that more vessels can be worked on in lesser time period. Such a policy must recognize that port revenue levels are directly affected more by cargo traffic vessel traffic and turnover while ship turnaround time affects directly port choice by operators and vessel traffic. Port investment policy that recognizes the role of adequate provision of port infrastructure will thus cause decline in ship turnaround time, while improving cargo throughput and port revenue.

The test of Hypothesis $\mathrm{H}_{01}$ shows a t-stat of 2.393 and t-critical of 1.73, and a P-value of 0.089 . Since p-value is less than 0.05 , that is, $0.089<0.05$, we reject null hypothesis $\mathrm{H} 01$ to conclude that there is a significant impact of cargo throughput on port revenue within the period covered by the study. The test of hypothesis $\mathrm{H}_{02}$ shows a t-stat of 0.822 , t-critical of 1.73 and p-value of 0.427 . Since $0.427>0.05$, we accept H02 and conclude that there no significant impact of vessel turnaround time on port revenue.

The result of the trend analysis using time as the dependent variable on table 3 indicates that the quantitative model depicting the trend of port revenue, cargo throughput and vessel turnaround time are:

Ytr $=128.4+1.82 \mathrm{y}+\mathrm{e}, \mathrm{X} 1 \mathrm{tr}=80.47+0.631 \mathrm{X} 1+\mathrm{e}, \mathrm{X} 2 \mathrm{tr}=10.54+0.574 \mathrm{X} 2+\mathrm{e}$ respectively.

The test of hypothesis $\mathrm{H} 03$ indicates positive gradients of $1.82,0.631$, and 0.574 for port revenue, cargo throughput and ship turnaround time. This indicates an increasing trend in port revenue, cargo throughput and ship turnaround time. Thus, we reject hypothesis $\mathrm{H} 03$ and conclude that there is a significant increase in port revenue, cargo throughput and vessel turnaround time. This is similar to the earlier result obtained by plotting port revenue against cargo throughput and ship turnaround time respectively.

The policy implication is that as vessel turnaround maintain a continuous increase in trend alongside cargo throughput and port revenue, utility derivable by ship operators (port customers) for port service consumption cannot be maximized but may rather decline. Since longer stay in port or at berth means that more money is paid for time wastages due to poor infrastructural condition and low services. Port authorities will therefore loose customers and subsequently revenue.

6.1 Answers to research questions

(1) The quantitative impact of cargo throughput on port revenue within the period covered in the study is expressed by 
the equation $\mathrm{Y}=106.22 \mathrm{X} 1-10753.216+\mathrm{e}$. This shows significant impact as evidenced by the rejection of hypothesis $\mathrm{H} 01$.

(2) The acceptance of hypothesis $\mathrm{H}_{02}$ proves that vessel turnaround time does not show significant impact on port revenue.

(3) Yes, there is a significant increase in port revenue, cargo throughput and ship turnaround time within the period.

\section{Conclusion}

The researcher has been able to achieve the objectives of the research as evidence from the analysis of data and findings indicates that cargo throughput have significant impact on port revenue. However, ship turnaround time showed no significant effect on port revenue over the period covered in the study. In reference to the third objective of the study, port revenue, cargo throughput and ship turnaround time, all shows significant increase in trend over the period. The model depicting the relationship that exist among port revenue, cargo throughput and ship turnaround is: $\mathrm{Y}=106.22 \mathrm{X} 1$ $+55.064 \mathrm{X}_{2}-10753.216+\mathrm{e}$.

\section{Recommendations}

The drive of port authorities has always been to generate more and optimize their impact on economic development of the nations and social welfare of staff. Based on the findings of the research, it is recommended that:

(1) Port authorities must concentrate more attention on developing policies that have potentials of securing more cargo to the ports to maximize cargo throughput volume, since cargo throughput has proved to contribute more to or impact more on port revenue. New policies made to attract more cargo volumes to the port will lead to improvement in port revenue.

(2) Though ship turnaround time failed to show significant impact on port revenue. It however showed a significantly increasing trend. This is bad and must be redirected to start a declining trend if the port must retain its present customers and attract more. It is therefore recommended that port investment policies must be redirected to provide adequate port infrastructure for quick vessel handling, so as to cause declining trend invessel turnaround time, improve vessel traffic volume, cargo throughput and port revenue.

\section{Suggestion for further research}

It is suggested that further research be carried out on the 'analysis of the effects of ship turnaround time on vessel traffic statistics of Nigerian ports' This is important because ship operators constitute vital port customers who must surely be suffering the increasing trend in ship turnaround time in ports as found in this study. They stay longer in port than supposed and pay higher port charges. The need to understand the response of ship operators to this anomaly gives rise to the need to investigate the impact or effect of ship turnaround time on vessel traffic statistics of the ports.

\section{Acknowledgements}

We sincerely acknowledge the Nigerian Ports Authority, Lagos port complex for the release of the data with which this work was carried through the annual reports. I am equally indebted to Dr. Obed Ndikom of the Department of Maritime Management Technology, Federal University of Technology, Owerri, Nigeria for his all-round support to enable this work be done.

\section{References}

[1]. Chrizanosky, A., (1985). An introduction to shipping economics. London, fairplay.

[2]. Amadi, E., (2014]. An analysis of the effects of transit and warehousing costs on port services. unpublished B.tech. thesis in the department of maritime Management, Federal University of technology, Owerri.

[3]. Ihenacho, E, (2005). Policy imperative for development of viable shipping industry: A paper presentation at a shipping stakeholder's forum at lagoon restaurant , Victoria Island, Lagos on 15th sept. Organized by national maritime authority

[4]. Adebayo, D., (2005). Loss of revenue at the ports. A re-appraisal of the 2001 port reforms. A paper presented at the $4^{\text {th }}$ national conference of all maritime stakeholders summit, airport hotels, Apapa,

[5]. Badejo, B. A., (2000). The role and implication of Governmental policies in charting the course of the maritime industry. A paper presented at the national seminar on eradication of corruption and sharp practices in our seaports. 24-26th October.

[6]. Baird, A.J., (2006). Optimising the container transhipment hub location in northern europe. Journal of Transport Geography 2006(14): 195-214.

[7]. Kendall, H .B., Stent A .F., (2001). A scheduling model for a high speed containership service: A hub and spoke short-sea application. International Journal of Maritime Economics 2001(3 \}: 262-277.

[8]. Fagerholt K., Lindstad, H., (2000). Optimal policies for maintaining a supply service in the Norwegian Sea. Omega 2000 (28): 269-275.

[9].Filani M.O., Shomoyiwa, B., (2009). Productivity assessment of Apapa Container Terminal. Paper presentation at ports and terminal conference, Lagos, June $2^{\text {nd }}, 2009$.

[10]. Maduka, J.H.O.,(2004). Ports, safety and environmental Management. Lagos, Concept Publications.

[11]. Mourao M.C., Pato, M.V, Paixao, A.C., (2001). Ship assignment with hub and spoke constraints. Maritime Policy \& Management 2001(29): 135-150. 
[12]. Olson C.A, Sorenson, E.E, Sullivan, W.J., (1969). Medium-range scheduling for a freighter fleet. Operations Research journal 1969(17): 565-582.

[13]. Ndikom, O.B., (2013). Fundamentals of freight forwarding practice in Nigeria. Lagos, Bumico publishers.

[14]. NPA, (2014). Nigerian ports authority annual statistical bulletin. 